\title{
OB I T UARIES
}

\section{Mr. William Macnab, C.B.E.}

$\mathrm{B}^{\mathrm{r}}$ $Y$ the death of Mr. William Macnab, on September 2 , at the ripe age of eighty-four, we have to record the loss of one who not only made original contributions to our knowledge of explosives, both as to their properties and manufacture, but who in addition must be considered as a pioneer in the recognition of the importance of chemical engineering in Great Britain.

Coming from Greenock, his father being a shipbuilder there, he took up the subject of sugar chemistry, after a training at the University of Glasgow, where he made a life-long friendship with Ramsay. Fond of travelling, he spent some time in Germany in connexion with sugar and later in Canada and the United States; in Siberia also he passed an adventurous two years engaged in prospecting. $\mathrm{He}$ could converse readily in French, German and Russian.

About the age of thirty Macnab took up a consulting practice in partnership with C. Napier Hake and carried this on after his partner had left for Australia to become Inspector of Explosives for Victoria. It was at this period and in collaboration with Napier Hake that he undertook the translation and collation of Berthelot's papers on explosives, publishing in 1892 "Explosives and their Power", which is a handbook constantly referred to by all explosives chemists. This book describes the application of thermochemistry to explosives, gives Berthelot's calorimetric data for explosive reactions over a wide field and deals with many explosive phenomena.

At this time Macnab began his original contributions to the study of explosives, and with E. Ristori published researches on partially gelatinized and on fully gelatinized propellants (Proc. Roy. Soc., 56, 8 ; 1894). A bomb of the Berthelot type was used; heat values and volumes of gases given off with their composition were measured, together with the metamorphosis undergone by gelatinized mixtures of nitroglycerine with various nitrocelluloses when exploded in the bomb. This work had importance as well as accuracy, as was shown by the agreement of products with original composition of explosive. Pressures were measured in another bomb and these agreed with the values found by Sir A. Noble. Later (Proc. Roy. Soc., $66,221 ; 1900)$ the same authors described attempts to determine the temperature of explosion (apart from its calculation from heat values and specific heats) by a method depending on the use of thermocouples of gradually decreasing diameter, the deflex. ion of a galvanometer mirror being photographically recorded. Although absolute values for temperature were not obtained, the results placed different explosive mixtures in a comparative sequence. This subject was continued in collaboration with A. E. Leighton (J. Soc. Chem. Ind., 23, 298; 1904) when the heat values were compared with the galvanometer throws, the order of the powders being broadly the same in both cases.

Always interested in chemical manufacture, Macnab played an important part during the War of 1914-18, when he became a technical adviser on Lord Moulton's staff, where full use was made of his experience in the manufacture, as well as knowledge of the properties, of explosives. Working in close conjunction with Kenneth B. Quinan he was intimately associated with the design of factories for high explosives and propellants, as well as with their administration when erected. Impressed by Quinan's method of holding monthly meetings of his factory staffs at which costs and efficiencies were minutely discussed, resulting in notable improvements in technique, Macnab undertook after the War the compilation of an important series entitled "Technical Records of Explosives Supply, 1915-1918" (H.M. Stationery Office), dealing with intermediates and finished explosives. These are valuable studies in which the chemical engineering aspect is emphasized, and serve as text-books for any school in that subject, for they include not only the theory of the processes, but also sketches of designs of plants, instructions for running them, calculations of heat-transfer and loss, and choice of materials of construction. They are so framed as to assist a student engaged in general chemical engineering problems, not necessarily those dealing with explosives.

This methodical approach appealed to Macnab, who lectured on the subject at University College, London, and led to his support in starting the Department of Chemical Engineering there. This movement was strongly urged by Quinan also who had felt the grievous lack of chemical engineers during the War of 1914-18. Some chemical achievements during this time were described by Macnab in his Hurter Memorial Lecture in 1922. For the same reason he acted as one of the founders of the Institution of Chemical Engineers, becoming its president in 1934, the William Macnab Medal of that Institution commemorating his name. Much of the success of the Seventh International Congress of Applied Chemistry in 1909 was due to him. For his work in the War he was made a C.B.E. in 1920.

Of striking appearance, suggesting robust health, with rosy cheeks and pointed beard, always dressed with perfect neatness, he will be remembered for his geniality and unselfish kindliness; and his friends will remember the hospitality of his charming wife and himself at his house on the river, where it was his custom to entertain them, take them out in one of his craft, for he was a master sailor, and to some of them show his experiments in calorimetry with a large bomb that needed his athletic frame to manhandle. In his London house also, his skill at the piano and liking for good music will be remembered by many.
ROBERT ROBERTSON. 